Article abstract-We reviewed the correlation between malignant cells in cerebrospinal fluid (CSF) (positive cytology) and pathologic findings at autopsy. The purpose was to discover: (1) the incidence of negative CSF cytology in patients with CNS malignancy, (2) the incidence of false-positive cytology, and (3) the relationship between a true-positive cytology and the distribution of malignant tumor at autopsy. Of 117 patients with CNS tumor and premortem cytologic examination of the CSF, 31 (26 percent) were positive and 86 ( 74 percent) were negative. Only 1 of 66 patients with tumor that did not reach the leptomeninges had a positive cytology. Of 51 patients with leptomeningeal tumor at autopsy, cytology was positive in 30 (59 percent) and negative in 21 (41 percent). Five potentially "false-positive" cytologies were encountered: Three patients were treated, and tumor may have been eradicated; in two patients with lymphoma, inflammatory cells associated with infection were apparently mistaken for malignant cells. These data indicate that a positive CSF cytology is a reliable indicator of CNS malignancy and almost always reflects leptomeningeal tumor.

\title{
Malignant cells in cerebrospinal fluid (CSF): The meaning of a positive CSF cytology
}

J. Peter Glass, M.D., Myron Melamed, M.D., Norman L. Chernik, M.D., and Jerome B. Posner, M.D.

Examination of the cerebrospinal fluid (CSF) for malignant cells is a time-honored and widely used technique. Since DuFour ${ }^{1}$ first identified malignant cells in the CSF in 1904, many reports attest to the usefulness of CSF cytology in assisting in the diagnosis of primary and metastatic central nervous system (CNS) tumors. ${ }^{2-11}$ In most series, a "positive cytology"-i.e., malignant cells in CSF sampled from the lumbar sac, cistern, or lateral ventricles-was encountered in 20 to 40 percent of patients harboring malignant tumors of the CNS. Most of these reports dealt with only small numbers of metastatic tumors and did not address three major clinical considerations: (1) the incidence of negative CSF cytology in patients with histologically proved brain or, especially, leptomeningeal tumors, (2) the incidence of falsepositive cytology, and (3) the relationship between positive cytology and distribution of the tumor at autopsy. Since all of these clinical considerations have therapeutic implications, we reviewed our experience with cytologic examination of the CSF in patients subsequently examined at autopsy. Because of the nature of Memorial Sloan-Kettering
Cancer Center's (MSKCC) hospital population, this report deals largely with CNS metastases rather than with primary brain tumors.

Materials and methods. The records of the Cytology Laboratory and the Autopsy Service of MSKCC for the years 1976 and 1977 were compared. We identified all patients who had cytologic examination of the CSF prior to death, whether positive or negative, and who subsequently underwent autopsy that included the CNS. The pathologic examination of the nervous system was performed by one neuropathologist (N.L.C.) using a standardized coding system ${ }^{12}$ that emphasizes the extent and distribution of disease. Because of our interest in leptomeningeal metastases, special attempts were made to identify this neurologic complication of systemic cancer. ${ }^{13}$ Patients harboring CNS neoplasms were classified into three groups: (1) those with dural metastases, including invasion of the cavernous space, other dural sinuses or the subdural surface of brain or spinal cord; (2) those with parenchymal tumors within the substance of the brain or spinal cord; and (3)

From the Departments of Neurology and Pathology, Memorial Sloan-Kettering Cancer Center, and the Departments of Neurology and Pathology, Cornell University Medical College, New York, NY.

Accepted for publication March 19, 1979

Address reprint requests to Dr. Posner, 1275 York Avenue, New York, NY 10021 


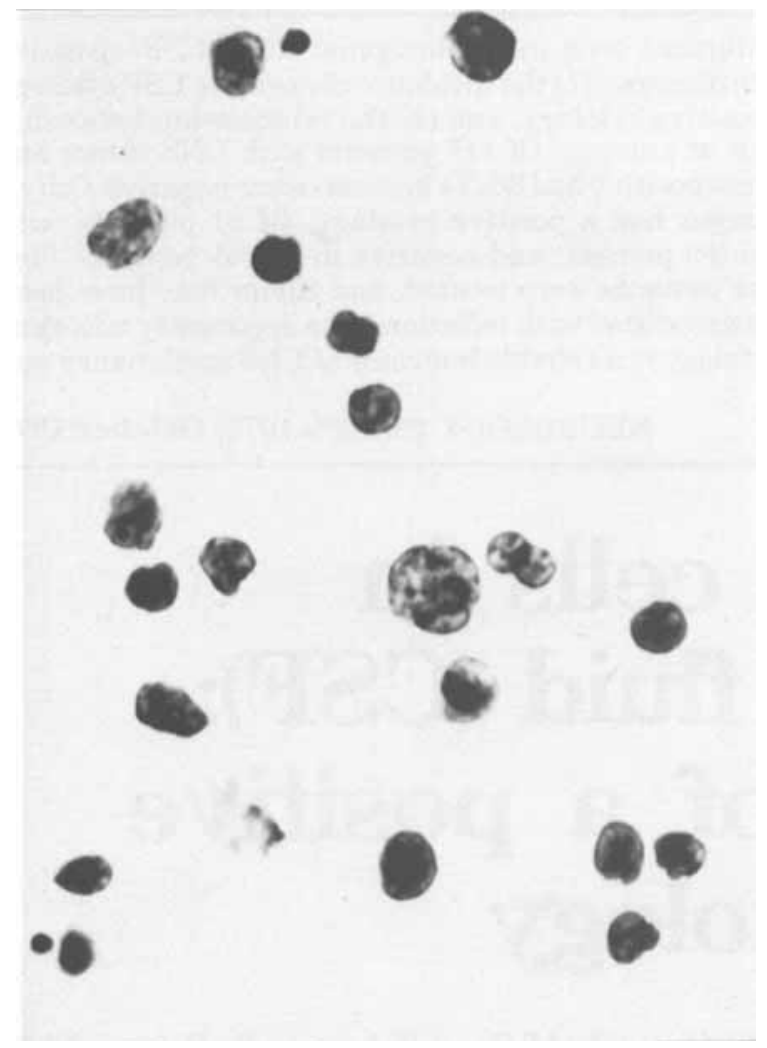

Figure 1. CSF cytology from a patient with malignant lymphoma. The spinal fluid is very cellular, and is composed of immature and abnormal lymphoreticular cells that are characteristically single rather than in groups. The cells vary in size, with little or no visible cytoplasm, and have irregular and convoluted nuclei with visible nucleoli.

those with leptomeningeal metastases. This last group was subdivided into patients with only a single focus of neoplasia in the leptomeninges and patients with diffuse or widespread multifocal seeding of the leptomeninges.

The findings on CSF examination were taken from the official reports. Only those reports in which malignant cells were definitely identified were considered positive (figures 1 to 3 ). "Suspicious" or "equivocal" findings were considered negative. The microscopic slides of the CSF reported as positive for malignant cells from patients with no evidence of CNS tumor at autopsy (falsepositive cytology) were examined again by one of the authors (M.M.). The usual CSF sample submitted to the Cytology Laboratory was obtained by lumbar puncture and contained approximately 4 cc of CSF immediately fixed with 4 cc of 50 percent alcohol. Smears were prepared from the centrifuged sediment or by direct centrifugation onto glass slides, and subsequently stained with the Papanicolaou technique. We do not use filter preparations.
Results. Autopsy findings. During 1976 and 1977 there were 777 autopsies of patients who died with malignant neoplasms and whose brains and spinal cords were examined; 363 of these patients were considered to be "neuropathology cases," requiring more careful examination because the patient had been evaluated neurologically during life or because a suspicious CNS lesion was encountered by the prosector on gross or microscopic examination. In 210 patients, tumor was found in CNS (table 1).

One hundred forty-two patients had malignant tumors within the parenchyma of the brain or spinal cord. In 98 of these patients, there was no evidence of leptomeningeal or dural involvement; in the other 44 there was additional tumor in the leptomeninges as well as the brain or spinal cord. These 142 parenchymal lesions include 114 metastatic lesions and 28 primary CNS tumors (table 1).

Fifty patients had dural lesions. All were metastatic; 33 had no additional leptomeningeal involvement, and in 17 leptomeningeal metastases accompanied the dural involvement. Seventythree patients had histologic evidence of leptomeningeal tumor, either metastases from a systemic cancer or direct spread from a primary brain tumor. In 18 patients, leptomeningeal tumor was unaccompanied by parenchymal or dural neoplasia; in 41 patients there were also parenchymal lesions, and in 14 there were dural tumors.

CSF cytology. During 1976 and 1977, 2775 individuals underwent cytologic examination of the CSF. These included 182 of the 363 "neuropathology cases" and 117 patients with histologically proved CNS malignancy (table 2). The interval

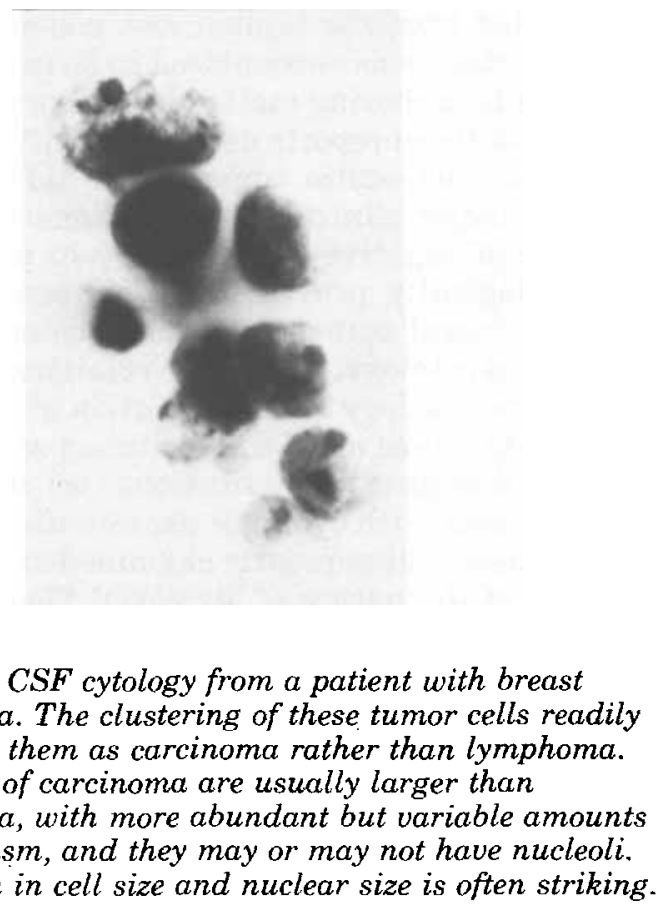

Figure 2. CSF cytology from a patient with breast carcinoma. The clustering of these tumor cells readily identifies them as carcinoma rather than lymphoma. The cells of carcinoma are usually larger than lymphoma, with more abundant but variable amounts of cytoplasm, and they may or may not have nucleoli. Variation in cell size and nuclear size is often striking. 


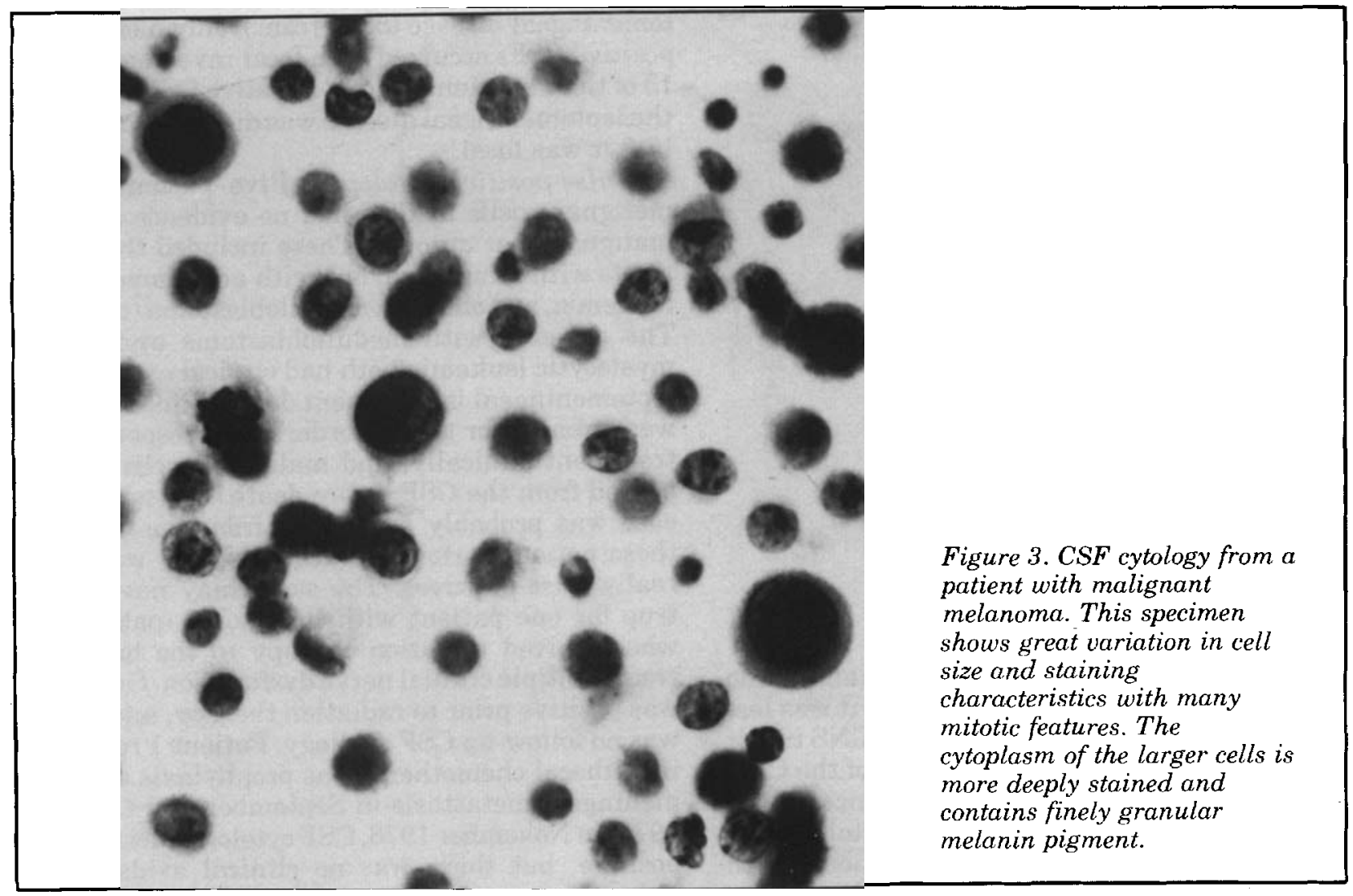

Table 1. CNS tumors encountered at autopsy (1976-1977)

\section{Tumor type}

Primary brain tumor

Malignant astrocytoma

Medulloblastoma

Meningioma

Solid systemic tumor

Breast

Lung

Melanoma

Gynecologic malignancies

Testicular malignancies

Neuroblastoma

Renal carcinoma

Osteogenic sarcoma

Others

Hematologic malignancies

Leukemia

Hodgkin disease

Non-Hodgkin lymphoma

Myeloma

Totals
Site of CNS involvement

Parenchymal Dural Leptomeningeal

$\begin{array}{rlllll}25 & (19)^{*} & 0 & (0)^{*} & 6 & (0) \dagger \\ 2 & (1) & 0 & (0) & 1 & (0) \\ 1 & (0) & 0 & (0) & 0 & (0)\end{array}$

28 (18)

7 (4)

$14 \quad(2)$

$33(26)$

4 (2)

$10 \quad(1)$

13 (9)

1 (0)

$6 \quad(2)$

5 (5) $\quad 1 \quad(1) \quad 0 \quad(0)$

$\begin{array}{llllll}4 & (4) & 1 & (1) & 0 & (0)\end{array}$

$\begin{array}{llllll}0 & (0) & 4 & (1) & 3 & (0)\end{array}$

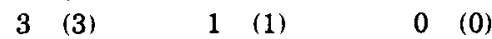

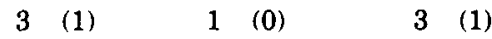

$\begin{array}{lllllll}13 & (9) & & 9 & (9) & & 4\end{array}$

$\begin{array}{rrrrrr}7 & (3) & 11 & (8) & 14 & (7) \\ 2 & (0) & 3 & (3) & 2 & (0) \\ 3 & (0) & 5 & (2) & 9 & (4) \\ 0 & (0) & 2 & (1) & 1 & (0) \\ 142(98) & 50 & (33) & 73 & (18)\end{array}$

* Figures in parentheses represent patients with parenchymal or dural tumor but without leptomeningeal invasion.

+ Figures in parentheses represent patients with leptomeningeal tumor but without parenchymal or dural tumor. 
Table 2. CSF cytology in patients with CNS malignancies

\begin{tabular}{|c|c|c|c|}
\hline & Total no. & $\begin{array}{l}\text { Cytology } \\
(+)\end{array}$ & $\begin{array}{c}\text { Cytology } \\
(-)\end{array}$ \\
\hline No leptomeningeal tumor & 66 & $1^{*}$ & 65 \\
\hline Parenchymal metastases & 42 & & 42 \\
\hline Primary CNS tumors & 8 & $1^{*}$ & 7 \\
\hline Dural metastases & 16 & 0 & 16 \\
\hline Leptomeningeal tumor (plus) & s) 51 & 30 & 21 \\
\hline Parenchymal metastases & 22 & 12 & 10 \\
\hline Primary CNS tumors & 6 & 5 & 1 \\
\hline Dural metastases & 8 & 5 & 3 \\
\hline LM alone & 15 & 8 & 7 \\
\hline Total & 117 & 31 & 86 \\
\hline
\end{tabular}

between the last antemortem CSF examination and death varied, but in most patients it was less than 30 days. Of the 117 patients with CNS tumor and premortem cytologic examination of the CSF, 31 (26 percent) were positive at least once and 86 (74 percent) were negative. The CSF cytology was negative in all except 1 of the 66 patients with parenchymal or dural lesions without leptomeningeal involvement. Of the 22 patients with both parenchymal disease and leptomeningeal disease, there were 12 positive cytologies and 10 negative cytologies. In the eight patients with leptomeningeal involvement in addition to dural tumor, there were five positive and three negative cytologies. Thus, in only one instance were malignant cells found in the CSF of patients whose meninges were not invaded by tumor at autopsy, and that patient's cytology reverted to negative with treatment, which may have eradicated previously present leptomeningeal disease.

The CSF was examined before death in 51 of the 73 patients with autopsy-proved leptomeningeal tumor. These include metastases from a variety of primary tumors (table 3 ); in 30 patients (59 percent), the cytology was positive and in 21 it was negative. No primary tumor appeared to exude cells into the CSF more consistently than any other. The incidence of positive cytologies correlated with the extent of disease (table 4). Of the 73 patients with leptomeningeal metastases, the disease was focal in 19 and multifocal or disseminated in 54. Among the 13 patients with focal leptomeningeal seeding and CSF examination, 5 cytologies were positive ( 38 percent) and 8 negative. Of the 38 patients with disseminated leptomeningeal tumor and CSF examination, 25 were positive (66 percent) and 13 negative (figure 4). When viewed the other way, 25 of 30 patients with a positive CSF cytology had disseminated lep- tomeningeal disease ( 83 percent); only 5 of the 30 positive CSFs occurred with focal involvement. In 13 of the 21 patients with a negative CSF cytology the leptomeningeal disease was disseminated, and in 8 it was focal.

"False-positive cytology." Five patients with malignant cells in CSF had no evidence of CNS malignancy at autopsy. These included three patients with lymphoma, one with acute myelocytic leukemia, and one with medulloblastoma (table 5). The patients with medulloblastoma and acute myelocytic leukemia both had clinical evidence of leptomeningeal involvement during life, and both were treated for that disorder. Both responded to treatment clinically, and malignant cells disappeared from the CSF before death. Thus, the disease was probably eradicated from the CNS in these patients prior to death, and they were not really false-positives. The same may have been true for one patient with lymphoma (patient 3 ) who received radiation therapy to the brain to treat multiple cranial nerve dysfunction. Cytology was positive prior to radiation therapy, and there was no follow-up CSF cytology. Patient 1 received intrathecal chemotherapy as prophylaxis against meningeal metastasis in September and October 1975. In November 1976, CSF cy tology was read as positive, but there was no clinical evidence of either leptomeningeal tumor or meningitis. CSF cultures for bacteria and fungi were negative, and all other CSF measurements were normal. There was no known cause for the positive cytology. $\mathrm{Pa}$ tient 2 was also a true false-positive. Apparently malignant cells appeared in the CSF in association with disseminated herpes zoster and symptoms of herpes zoster meningitis. No therapy was given to the CNS for malignant lymphoma, and when the generalized zoster cleared the CSF cytology became negative.

Discussion. We undertook this retrospective analysis of cytologic examinations of the CSF for three reasons: (1) It had been our clinical impression that positive cytology was strong evidence that a malignant brain tumor had not only reached the ventricular or leptomeningeal surface but had seeded the leptomeninges, at least in focal areas. Although it had been recognized that tumor cells could not appear in the CSF unless they reached the leptomeningeal or ventricular surface, ${ }^{7,8,14}$ few attempts had been made to correlate the findings in the CSF with the presence and extent of leptomeningeal seeding at autopsy, and it has been implied that parenchymal lesions can and do exude malignant cells into the CSF. Since we consider malignant cells in the CSF as presumptive evidence of meningeal seeding, and treat patients on that basis, this is of clinical importance. (2) We were also concerned about the possibility of falsepositive cytologic diagnoses. In recent years we 
Table 3. Leptomeningeal involvement by systemic tumor

$\begin{array}{lcccc}\text { Tumor type } & \text { No. patients } & \begin{array}{c}\text { No. CSF samples } \\ \text { examined }\end{array} & \begin{array}{c}\text { Cytology (+) } \\ \text { Cytology (-) }\end{array} \\ \text { Breast } & 14 & 10 & 6 & 4 \\ \text { Lung } & 10 & 6 & 3 & 2 \\ \text { Melanoma } & 6 & 3 & 1 & 0 \\ \text { Neuroblastoma } & 3 & 2 & 0 & 1 \\ \text { Osteogenic sarcoma } & 3 & 2 & 4 & 2 \\ \text { Leukemia } & 14 & 9 & 5 & 5 \\ \text { Lymphoma } & 11 & 8 & 5 & 3 \\ \text { Primary brain tumors } & 7 & 6 & 2 & 3 \\ \text { Other } & 5 & 5 & 30^{*} & 21\end{array}$

* Excludes one patient with primary CNS tumor and positive cytology.

Table 4. CSF cytology and extent of leptomeningeal disease

$\begin{array}{lcccc} & \text { No. patients } & \begin{array}{c}\text { No. CSF samples } \\ \text { examined }\end{array} & \begin{array}{c}\text { Cytology (+) } \\ \text { Cytology (-) }\end{array} \\ \text { Focal seeding } & 19 & 13 & 5 & 8 \\ \text { Primary } & 1 & 1 & 0 & 1 \\ \text { Metastatic } & 18 & 12 & 5 & 7 \\ \text { Multifocal/disseminated seeding } & 54 & 38 & 5 & 13 \\ \text { Primary } & 6 & 5 & 5 & 0\end{array}$

have encountered an increasing number of positive cytologic diagnoses, and we occasionally considered some to be falsely positive. There have been several reported cases of false-positive CSF cytology in malignant lymphomas ${ }^{8}$ at times associated with CNS infections. ${ }^{8,15,16}$ A significant incidence of false-positive cytologic diagnoses would, of course, have major clinical implications. (3) Finally, we have been concerned about the patients with clinical (or pathologic) evidence of widespread leptomeningeal involvement in whom malignant cells are not found in the CSF. Since most physicians require a finding of malignant cells in the CSF to make a diagnosis of leptomeningeal tumor, we wanted to know how often cytologic examination was negative in patients with proved disseminated leptomeningeal tumor.

This survey appears to answer all three questions. At least in our hands, malignant cells in the CSF imply that the leptomeninges have been seeded by viable tumor. Moreover, tumor is usually not just present in a focal area of leptomeninges, but has seeded the leptomeninges rather widely in a multifocal or disseminated fashion. This statement applies not only to metastatic CNS neoplasms but also to primary tumors. Second, false-positive cytologic diagnoses appear to be rare, at least in our experience, and occurred only in patients with lymphoma who were suffering from meningitis in which reactive or immature lymphocytes were mistaken for malignant lymphoid cells. With experience, even most of these cases could be correctly recognized. Thus, in one report of a false-positive cytologic diagnosis, ${ }^{15}$ lymphocytes from the CSF of a patient suffering from cryptococcal meningitis were interpreted as lymphoma; we believe from the photomicrographs in that article that the cells can be identified as reactive.

False-negative CSF cytology in patients with 


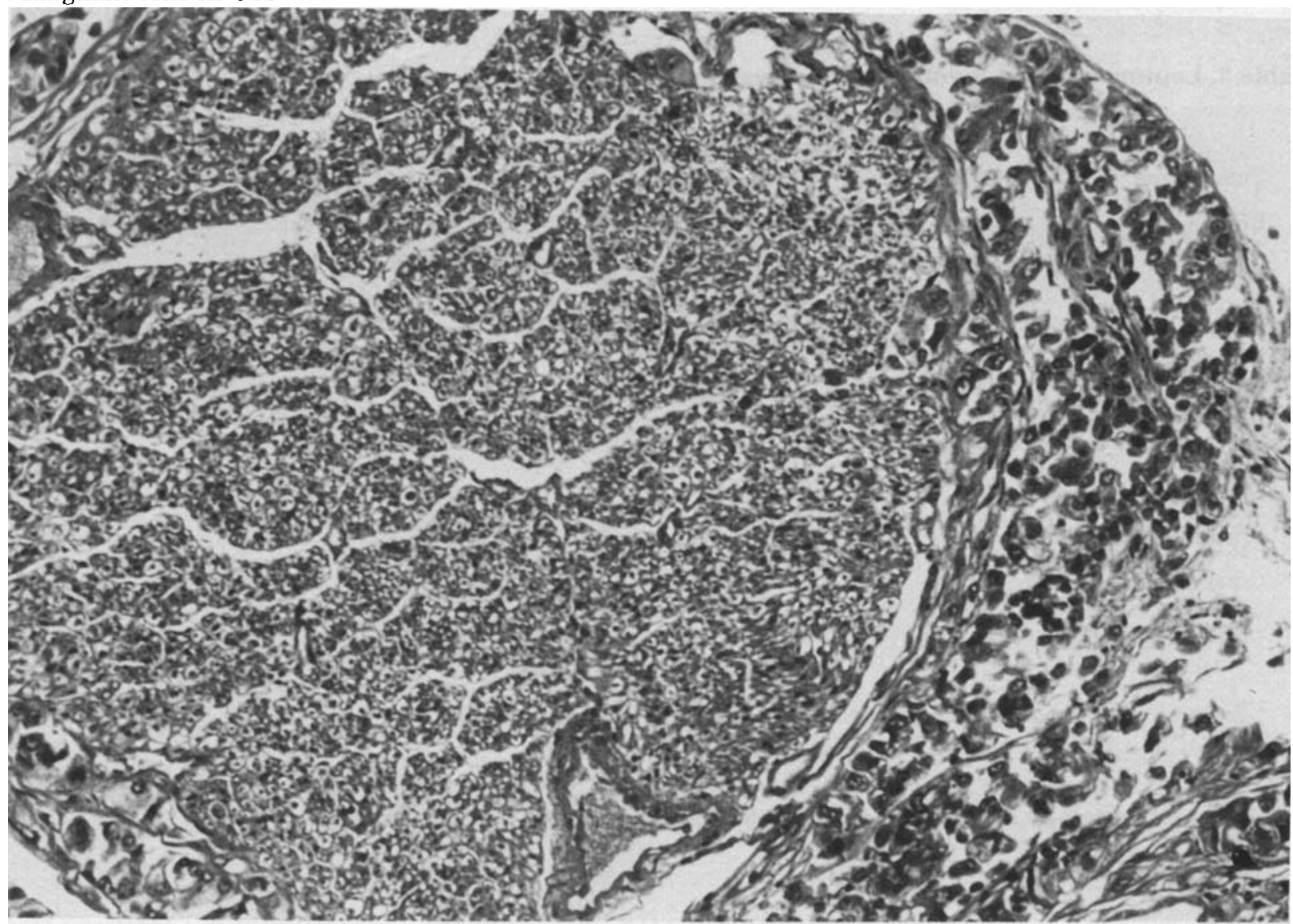

Figure 4. The cauda equina from a patient with a negative CSF cytology. This patient suffered from adenocarcinoma of the lung with clinical signs of widespread leptomeningeal involvement by tumor. Three lumbar punctures were performed 10 days prior to her death. In each there were an increased number of lymphocytes, an elevated protein level, and a depressed glucose level, but in all three instances the cytologic examination for malignant cells was negative. At autopsy, the day after the third lumbar puncture, the cauda equina was grossly infiltrated by tumor, and microscopic sections revealed large numbers of tumor cells surrounding each of the roots.

Table 5. Positive CSF cytology not confirmed at autopsy

\begin{tabular}{|c|c|c|c|c|c|c|}
\hline $\begin{array}{l}\text { Patient } \\
\text { no. }\end{array}$ & $\begin{array}{l}\text { Primary } \\
\text { tumor }\end{array}$ & $\begin{array}{l}\text { Positive } \\
\text { cytology }\end{array}$ & Treatment & $\begin{array}{l}\text { Negative } \\
\text { cytology }\end{array}$ & $\begin{array}{l}\text { Date of } \\
\text { death }\end{array}$ & Comments \\
\hline 1 & Lymphoma & $11 / 17 / 76$ & $\begin{array}{l}\text { None following } \\
\text { cytologic exam }\end{array}$ & $\begin{array}{l}\text { No } \\
\text { follow-up }\end{array}$ & $11 / 21 / 76$ & $\begin{array}{l}\text { Probable } \\
\text { false-positive } \\
\text { associated } \\
\text { with sepsis }\end{array}$ \\
\hline 2 & Lymphoma & $4 / 19 / 76$ & None & $6 / 24 / 76$ & $11 / 21 / 77$ & $\begin{array}{l}\text { False-positive } \\
\text { effect of } \\
\text { herpes zoster }\end{array}$ \\
\hline 3 & Lymphoma & $1 / 16 / 76$ & $\begin{array}{l}\text { Radiation therapy } \\
\text { to the brain }\end{array}$ & $\begin{array}{l}\text { No } \\
\text { follow-up }\end{array}$ & $2 / 3 / 76$ & $\begin{array}{l}\text { Tumor may have } \\
\text { responded to treatment }\end{array}$ \\
\hline 4 & Leukemia (AML) & $9 / 21 / 76$ & $\begin{array}{l}\text { Radiation therapy } \\
\text { to base of skull } \\
\text { Intraventricular } \\
\text { methotrexate }\end{array}$ & $10 / 11 / 76$ & $10 / 29 / 76$ & $\begin{array}{l}\text { Good clinical } \\
\text { evidence of CNS } \\
\text { involvement } \\
\text { prior to treatment }\end{array}$ \\
\hline 5 & Medulloblastoma & $6 / 24 / 76$ & $\begin{array}{l}\text { Radiation therapy } \\
\text { to spinal cord } \\
\text { High-dose intravenous } \\
\text { methotrexate }\end{array}$ & $9 / 2 / 76$ & $6 / 3 / 77$ & $\begin{array}{l}\text { Good clinical } \\
\text { evidence of CNS } \\
\text { involvement } \\
\text { prior to treatment }\end{array}$ \\
\hline
\end{tabular}


widely disseminated leptomeningeal metastases is still a significant problem. It is well to remember that in a patient with appropriate clinical or other evidence of leptomeningeal tumor, absence of malignant cells in the CSF does not rule out that diagnosis.

Our findings differ from other surveys which suggested that parenchymal metastases without leptomeningeal involvement can be identified by examination of CSF. There are several possible reasons for this discrepancy: (1) Our techniques may be less sensitive than others, ${ }^{2,17}$ resulting in excessive false-negative cytologies unless the leptomeninges are widely seeded and large numbers of cells are actually present in the CSF. (2) Previous reports of positive cytologies in parenchymal tumors may not have examined the entire nervous system carefully enough to identify leptomeningeal spread of tumor, which was, in fact, responsible for the positive cytology. (3) We may be "underreading" malignant cells or others may be overreading malignant cells in the CSF. We believe that leptomeningeal metastases may be overlooked at autopsy if not specifically sought by meticulous examination of the entire CNS in patients with positive cytologies, a practice we have consistently followed. Overall, about 25 percent of our patients with autopsy-proved CNS involvement by malignant tumor had a positive cytology, a figure similar to that encountered in most other large series. Furthermore, when considered by individual tumor type, the percentage of cases with positive cytology seen by us was similar to that of other studies. Thus, the difference between our studies and others is not in the technique of isolating and identifying malignant cells in the CSF, but in the meticulous examination of the CNS at autopsy, revealing a much higher incidence of leptomeningeal seeding than was previously apparent.

Conclusions. We draw several conclusions from these data and our review of the literature: (1) Malignant cells in the CSF mean that there is malignant tumor in the CNS. In rare instances of patients with systemic lymphoma and CNS infection, immature or reactive lymphocytes in the CSF may mimic lymphoma and lead to errors in diagnosis. Occasional patients with systemic leukemia in blastic crisis may seed a few malignant cells into the CSF, but the implications of that are not entirely clear. (2) Malignant cells appear in the CSF most commonly when the leptomeninges are widely seeded by tumor, less often when they are focally seeded by tumor, and almost never when tumor is limited to the brain and the pial surface has not been breached. The clinical implication of this finding is that if malignant cells are present in the CSF, cure by ablative surgery is highly unlikely, and treatment must be directed to the en- tire neuraxis. (3) Failure to find malignant cells in the CSF does not exclude the diagnosis of leptomeningeal seeding when clinically suspected. An exception is acute lymphoblastic leukemia, which will almost always yield cells in the CSF if the meninges are seeded. (4) Cytologic examination of the CSF may be useful in assessing the results of therapy. Three of our patients with unequivocal clinical evidence of leptomeningeal seeding and positive CSF cytology reverted to negative during the course of treatment, and no tumor was found in their CNS at autopsy.

\section{References}

1. DuFour MH: Méningite sarcomateuse diffuse avec encahissement de la moelle et des racines: Cytologie positive et special du liquide céphalorachidien. Rev Neurol (Paris) 12:104-106, 1904

2. Gondos B, King EB: Cerebrospinal fluid cytology: Diagnostic accuracy and comparison of different techniques. Acta Cytol 20:542-547, 1976

3. Wertlake PT, Markovits BA, Stellar S: Cytologic evaluation of cerebrospinal fluid with clinical and histologic correlation. Acta Cytol 16:224-239, 1972

4. McMenemey WH, Cumings JN: The value of the examination of the cerebrospinal fluid in the diagnosis of intracranial tumours. J Clin Pathol 12:400-411, 1959

5. Balhuizen JC, Bots GTAM, Schaberg A, et al: Value of cerebrospinal fluid cytology for the diagnosis of malignancies in the central nervous system. J Neurosurg 48:747-753, 1978

6. Kline TS: Cytological examination of the cerebrospinal fluid. Cancer 15:591-597, 1962

7. Rich JR: A survey of cerebrospinal fluid cytology. Bull Los Angeles Neurol Soc 34:115-131, 1969

8. Naylor B: The cytologic diagnosis of cerebrospinal fluid. Acta Cytol 8:141-149, 1964

9. McCormack LJ, Hazard JB, Gardner WJ, et al: Cerebrospinal fluid changes in secondary carcinoma of meninges. Am J Clin Pathol 23:470-478, 1953

10. Wilkins RH, Odom GL: Cytological changes in cerebrospinal fluid associated with resections of intracranial neoplasms. J Neurosurg 25:24-34, 1966

11. El-Batata M: Cytology of cerebrospinal fluid in the diagnosis of malignancy. J Neurosurg 28:317-326, 1968

12. Chernik NL, McDowell LB: Work book: Neuropathology. In Gilbert HA, Posner JB, Weiss L (Editors). Brain Metastasis. Boston, GK Hall, 1979

13. Olson ME, Chernik NL, Posner JB: Infiltration of the leptomeninges by systemic cancer: A clinical and pathologic study. Arch Neurol 30:122-137, 1974

14. McGarry P, Holmquist ND, Carmel SA: A postmortem study of cerebrospinal fluid with histologic correlation. Acta Cytol 13:48-52, 1969

15. Davies SF, Gormus BJ, Yarchoan R, et al: Cryptococcal meningitis with false-positive cytology in the CSF: Use of T-cell rosetting to exclude meningeal lymphoma. JAMA 239:2369-2370, 1978

16. Rawlinson DG, Billingham ME, Berry PF, et al: Cytology of the cerebrospinal fluid in patients with Hodgkin's disease or malignant lymphoma. Acta Neuropathol (Berlin) [Supp] VI]: 187-191, 1975

17. Kajakawa $H$, Ohta $T$, Oshiro $H$, et al: Cerebrospinal fluid cytology in patients with brain tumours; a simple method using the cell culture technique. Acta Cytol 21:162-167, 1977 


\section{Neurology}

\section{Malignant cells in cerebrospinal fluid (CSF): The meaning of a positive CSF cytology}

J. Peter Glass, Myron Melamed, Norman L. Chernik, et al.

Neurology 1979;29;1369-1375

DOI 10.1212/WNL.29.10.1369

This information is current as of October 1,1979

\section{Updated Information \& \\ Services}

Citations

Permissions \& Licensing

Reprints including high resolution figures, can be found at: http://n.neurology.org/content/29/10/1369.full

This article has been cited by 19 HighWire-hosted articles:

http://n.neurology.org/content/29/10/1369.full\#\#otherartic les

Information about reproducing this article in parts (figures,tables) or in its entirety can be found online at: http://www.neurology.org/about/about_the_journal\#permi ssions

Information about ordering reprints can be found online: http://n.neurology.org/subscribers/advertise

Neurology ${ }^{\circledR}$ is the official journal of the American Academy of Neurology. Published continuously since 1951, it is now a weekly with 48 issues per year. Copyright (C1979Advanstar Communications, Inc.. All rights reserved. Print ISSN: 0028-3878. Online ISSN: 1526-632X.

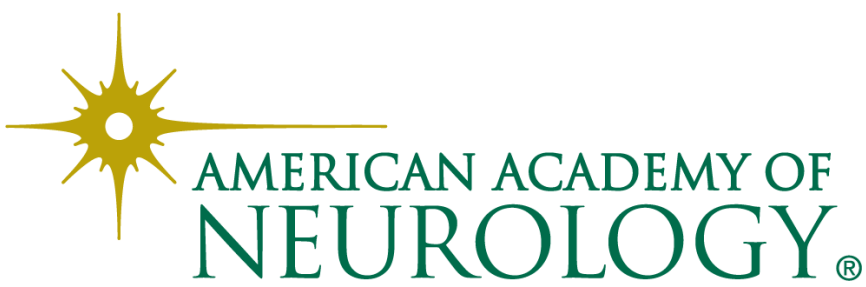

